\title{
Martensitic Transformations of Austenite below 273 K. Dilatometric and Magnetic Studies
}

\author{
I.A. Wierszyłłowski \\ Institute of Materials Science, Poznań University of Technology, Pl. Skkodowskiej-Curie 5, \\ 60-965 Poznań, Poland
}

\begin{abstract}
The transformation of austenite ( $\mathrm{Fe}-\mathrm{C}, \mathrm{Fe}-1.5 \mathrm{Cr}-1 \mathrm{C}, \mathrm{Fe}-\mathrm{N}, \mathrm{Fe}-\mathrm{Mn}-\mathrm{N}$ ) to martensite during quenching to the ambient temperature followed by cooling to $77 \mathrm{~K}$ was studied with a use of dilatometry and magnetic force measurements. We can see three transformations of austenite. The first during quenching, the second during cooling to $77 \mathrm{~K}$, and the third during an increase of temperature from $77 \mathrm{~K}$ to the ambient one. The first $40 \mathrm{minutes}$ of holding at ambient temperature influences most significantly the temperature of the second transformation of austenite. Temperatures of austenite transformation indicated as the increase of magnetic force during the third transformation are lower than that determined by increase of volume ( dilatometry). Amounts of austenite transformed during the third transformation determined by magnetic force measurements are somewhat higher than those determined by dilatometry.

The reasons of these differences are discussed on the basis of recent publications.
\end{abstract}

\section{INTRODUCTION}

During quenching of $\mathrm{Fe}-\mathrm{C}$ or $\mathrm{Fe}-\mathrm{N}$ alloys and steels from austenitizing temperature to a temperature below that, at which the martensitic transformation starts we obtain martensite (M) and a certain amount of retained austenite (RA).The RA can be transformed to the $M$ by subsequent cooling to temperatures below ambient - usually below $273 \mathrm{~K}$. The austenite (A) to $\mathrm{M}$ transformation below $273 \mathrm{~K}$ has been studied for over last 30 years in numerous publications [19]. According to [5-10] during cooling to temperatures about $220 \mathrm{~K}, \mathrm{M}$ with anomalously low tetragonality is produced. The martensitic transformation at low temperatures produced an additional decrease of the lattice parameter $(a)$ of RA [11] and plastic deformation of the A accompanying the martensitic transformation of high Ni [13]. During heating from temperatures lower than $220 \mathrm{~K}$ to the room temperature the tetragonality of "low temperature" $M$ increase to a value close to usual [9 ].Until now attention has been paid to highly alloyed steels. The aim of this work is to analyse the RA transformations below $273 \mathrm{~K}$ in low alloyed steel , alloy $\mathrm{Fe}-0.8 \mathrm{wt} \%$ $\mathrm{N}$, alloy Fe $-1 \mathrm{wt} \% \mathrm{~N}-0.5 \mathrm{wt} \% \mathrm{C}$, and to compare the results with results of earlier works. In certain conditions the RA stabilisation (important for practice of heat treatment ) takes place.

\section{EXPERIMENTAL}

The analysis was performed with a help of an Adamel LK02 quenching dilatometer and a magnetic balance [14]. Tube- like specimens for dilatometric and small rings for magnetic studies were austenitized in preliminary vacuum in the dilatometer, and quenched in the helium gas jet to the ambient temperature. Deep cooling was performed with a help of liquid nitrogen ( LN) to temperatures about $77 \mathrm{~K}$. Specimens were prepared from $100 \mathrm{Cr} 6$ steel , alloy $\mathrm{Fe}-0.8 \mathrm{wt} \% \mathrm{~N}$, alloy Fe-1 wt $\% \mathrm{~N}-0.5 \mathrm{wt}$. \% of $\mathrm{C}$. Alloys with $\mathrm{N}$ were prepared by gas nitriding, alloys with $\mathrm{N}+\mathrm{C}$ by gas nitrocarburising [ 21].

For $100 \mathrm{Cr} 6$ steel, four kinds of treatment were applied after austenitizing at 1173 for $10 \mathrm{~min}$ and quenching: 1. Immediate deep cooling to the LN temperature, and, because of evaporation of nitrogen, heating to the room temperature. 2. Deep cooling to $L N$, holding at this temperature 10,25 and $35 \mathrm{~min}$, heating to the room temperature and treatment according to 1 . 3. Holding at the room temperature 10,25, and $35 \mathrm{~min}$ and treatment according to 1 . 4. Ageing at 323, 373, 
413 and $433 \mathrm{~K}$ for 10,25 and $35 \mathrm{~min}$, cooling to the room temperature and treatment according to 1 . The aim of the treatments was to find relarion between temperature and time of treatment and Ms temperatures appearing after subsequent cooling below $273 \mathrm{~K}$.

For Fe-N and Fe-N-C alloys after austenitizing at $1043 \mathrm{~K}(\mathrm{Fe}-\mathrm{N})$ and $1070 \mathrm{~K}$ (Fe-N-C) for 5 min and quenching treatment 1 was applied. The stabilisation factor $\theta$, that is difference between $\mathbf{M s}_{\mathbf{1}}$ and $\mathrm{Ms}_{2}$ ( see Fig. 1 ) was determined for all treatments.

\section{RESULTS}

A standard dilatometric diagram for majority of deep cooling experiments is presented in Fig. 1 a) and similar magnetic ones in Fig. 2. A dilatometric diagram for specimens of $100 \mathrm{Cr} 6$ steel after holding at $77 \mathrm{~K}$ is shown in Fig. $1 \mathrm{~b}$ )
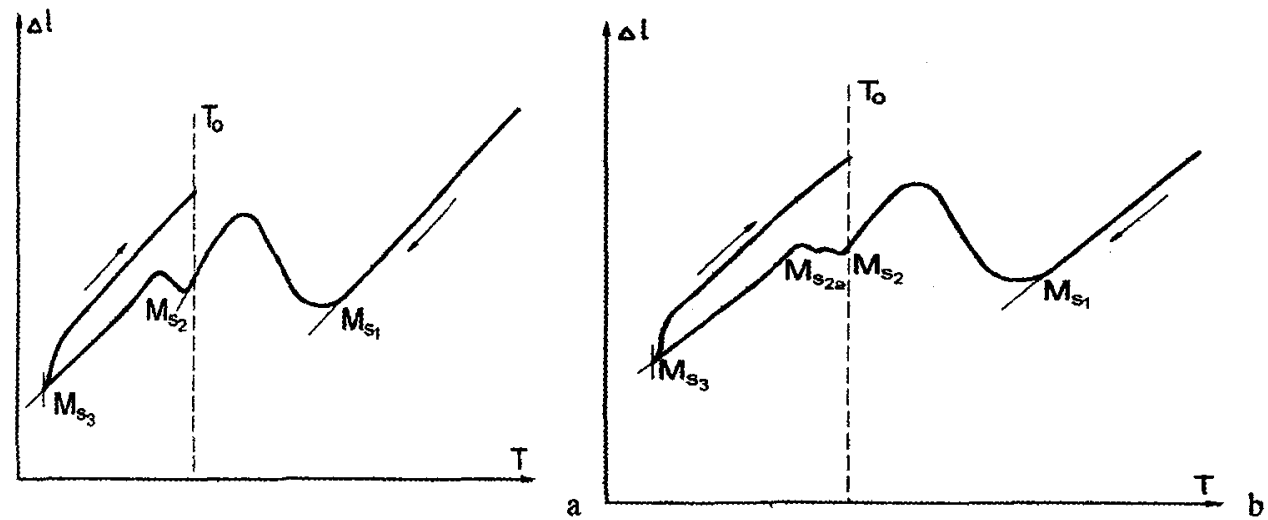

Figure 1. a) Standard dilatometric diagram after quenching and cooling in LN. b) Dilatometric diagram of $100 \mathrm{Cr} 6$ steel after holding at $77 \mathrm{~K}$.

We can see in Fig. 1a) - the $\mathrm{Ms}_{1}$ ( increase of volume ) temperature obtained during quenching, the $\mathrm{Ms}_{2}$ temperature obtained during deep cooling and the $\mathrm{Ms}_{3}$ temperature obtained during heating from the $\mathrm{LN}$ to room temperature. In Fig. 1 b) we can see the additional $\mathrm{Ms}_{2 \mathrm{a}}$ temperature appear during deep cooling.

The magnetic diagram ( see Fig.2) presents two temperatures for the beginning of the RA transformation to martensite (increase of the force with which the magnet attracts the specimen) $\mathbf{M s}_{2}$ and $\mathbf{M s}_{2}$, Both appear during deep cooling. The $\mathbf{M s}_{2}$, transformation starts during cooling and is continued during heating. The change of the $\mathrm{Ms}_{2}$ temperature, and the factor $\theta$ in dependence of holding temperature and time is shown in Fig. $3 \mathrm{a}$ and Fig. $3 \mathrm{~b}$ respectively. Changes of the $\mathrm{Ms}_{3}$ temperature as a function of holding time and temperature is shown in Fig. $3 \mathrm{c}$. The $\mathrm{Ms}_{2}$ temperature determined with a help of the magnetic method is lower than that determined with a help of dilatometry by about $50 \mathrm{~K}$ in the case of $100 \mathrm{Cr} 6$ steel and by about $30 \mathrm{~K}$ in the case of Fe$0.8 \mathrm{wt} \% \mathrm{~N}$ alloy. The $\mathrm{Ms}_{2}$, temperature appears during magnetic studies just before reaching the $\mathrm{L}$ $\mathrm{N}$ temperature, at temperature order of $80 \mathrm{~K}$. The total content of the transformed RA determined from dilatometric data (according to the method presented in $[14,16]$ ) is lower than that determined form magnetic data (the method presented in $[14,15,16]$ ), of the order of $3 \%$. 


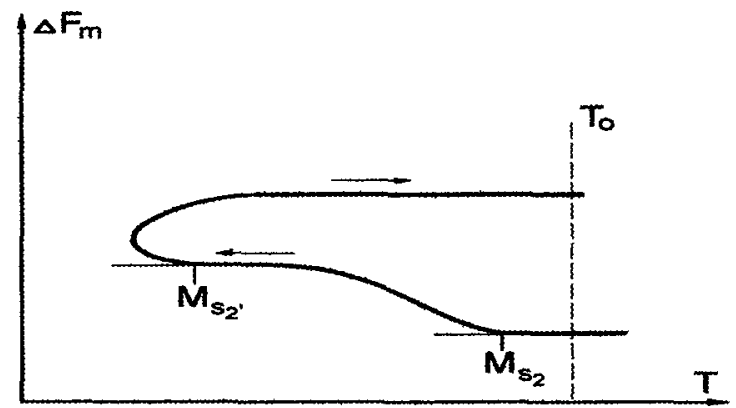

Figure 2. Standard magnetic diagram of specimens after quenching and cooling in LN.

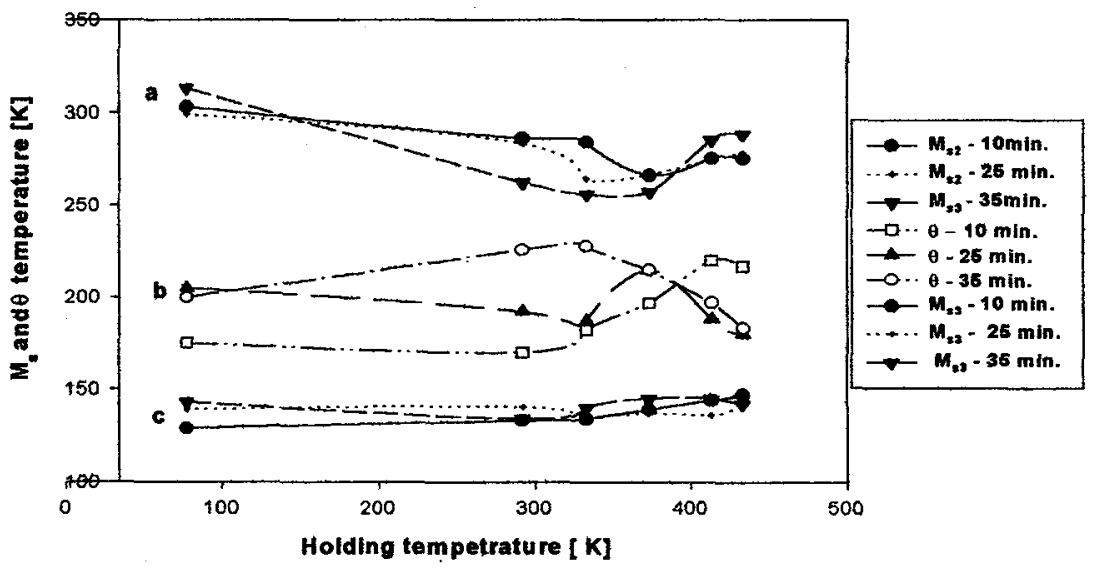

Figure 3. Changes of the $\mathrm{Ms}_{2}$ temperature (a), the $\mathrm{Ms}_{3}$ temperature (c) and the $\theta$ factor (b) as a function of holding time and temperature.

\section{DISCUSSION}

The most surprising result concerns the difference between $\mathrm{M}_{\$ 2}$ measured with a help of the magnetic method and the dilatometric one.

The difference appearing in these studies can be caused by the appearance of non ( or low) magnetic martensite at the beginning of RA-> martensite transformation , magnetisation will increase with the transformation progress. 
Total magnetisation of a ferromagnetic martensite depends on magnetic moment of $\mathrm{Fe}$ atoms and on nucleation and ordering of magnetic domains. Paramagnetic properties are identified by magnetometers only if domain ordering appears. Nucleation and domains ordering little depends on the structure of the $M[19]$ but much on the stresses $[19,20]$. High stresses appear on the ferromagnetic (martensite) /paramagnetic ( austenite) grains border [13,11 ]. High stresses should be overcome by magnetic domains passing through the material in order to achieve the ferromagnetic stage. This will only be possible by increase of outside magnetic field, or by higher mobility of atoms. Because of low temperature ( below ambient), mobility of atoms is small, higher magnetic field is necessary. This hypothesis was not proved because the increase of the magnetic field was impossible for the instrument applied.

The highest $\mathrm{Ms}_{2}$ temperature is obtained if holding temperatures are 77 and $433 \mathrm{~K}$ by $35 \mathrm{~min}$. (Fig.3). The lowest $\mathrm{Ms}_{2}$ temperature is obtained for holding temperatures within the range of 291$373 \mathrm{~K}$ by $35 \mathrm{~min}$. The stabilisation factor $\theta$ is the highest for temperatures order of $291-373 \mathrm{~K}$ by $35 \mathrm{~min}$, the smallest for holding time $10 \mathrm{~min}$ at 77 and $291 \mathrm{~K}$. The obtained results are in agreement with earlier studies $[23,25]$. The lowest $\mathrm{Ms}_{2}$ temperature agrees with the highest $\theta$, the highest $\mathrm{Ms}_{2}$ temperatures agrees with the lowest $\theta$. A low Ms temperature appears when the RA is resistant to the transformation to martensite, high if the RA is less resistant to the transformation [25-28]. The resistance of the RA to martensite transformation increases if its strength increases [26-28] and austenite strain embryos are not active [21,35-37].The strength of solid solution increases because of change of composition, inner structure ( dislocation density, plastic deformation, ) grain refining , ageing phenomena. The most probable is increase the strength of RA because of increase of interstitials ( C, N ) content in it [ 24,26,31,32 ], and plastic deformation of the RA regions at the M/RA border [13]. Simultaneously with this the deactivation of the martensite embryo in RA takes place. The deactivation is caused mainly by interstitials segregation to the embryo dislocations [ 37 ]. The same influence have the increase of planes number in the thickness of embryo [37].

On the dilatometric diagram after holding at $433 \mathrm{~K}$ by $35 \mathrm{~min}$. we can see a significant contraction [21], that means a significant decrease of specific volume of the specimen. A decrease of specific volume concerns martensite and causes a decrease of compressive stresses in the RA. At the temperature of $433 \mathrm{~K}$ carbon can diffuse in the $M$ and the R.A. along dislocations pipes. Carbon could be therefore moved away from M/RA border such that the average content is practically the same, it is proved by one $\mathrm{Ms}_{2}$ temperature. If certain volumes of the RA on the border of the M/RA are cold deformed at $433 \mathrm{~K}$, recovery of the RA could start and strength of the RA could slightly decrease. There are then, three reasons for high $\mathrm{Ms}_{2}$ : significant decrease of compressive stresses of the RA, partial recovery of cold deformed the RA, and more homogeneous distribution of $\mathrm{C}$ in the RA. Holding specimen at temperature of $77 \mathrm{~K}$ gives even a higher increase of $\mathrm{Ms}_{2}$. We should consider that the dilatometric diagram of the martensitic transformation consist of two parts - one with higher $\mathrm{Ms}_{2}$ and second with lower $\mathrm{Ms}_{2 \mathrm{a}}$ temperature. According to [10] because of stresses caused by the martensitic transformation the a parameter of the RA is reduced so that the volume of unite cell is smaller of about $1 \%$. The reduction is kept during worming up to the ambient temperature. According to [12] the martensite appearing during cooling to $77 \mathrm{~K}$ has a volume smaller than usual, the other studies [29] say that a unit cell volume remains the same. Holding in the $L N$ temperature causes that a part the RA has $\mathrm{Ms}_{2}$ temperature higher than $\mathrm{Ms}_{2 \mathrm{a}}$ ( see Fig. 1) of about $20 \mathrm{~K}$. It means that certain processes leading to strength reduction of a part of the RA took place or active austenite strain embryos appeared. The lowest $\mathrm{Ms}_{2}$ temperature is obtained for holding $35 \mathrm{~min}$. at 
temperatures within the range of 291-373 K. The stabilisation factor $\theta$ is the highest for this holding conditions. At that temperature range carbon redistribution processes took place in the $M$ [34] and the RA [30]. Carbon redistribution in $M$ in this temperature range may not release compressive stresses within the RA, especially on the M/RA border. These stresses accelerate diffusion of interstitial to dislocations within the RA. That may lead to deactivation of the austenite strain embryo from which martensite transformation starts [30,36,37]. During subsequent cooling much higher undercooling is necessary in order to create austenite strain embryos and start the martensitic transformation.

The lowest $\mathrm{Ms}_{3}$ temperature was obtained after holding the specimens for $10 \mathrm{~min}$ in $77 \mathrm{~K}$, the highest after holding at $433 \mathrm{~K}$ by $10 \mathrm{~min}$. Because $\mathrm{Ms}_{3}$ appears during heating, low temperature of transformation means that energy supply necessary to the RA transformation to $M$ is small , high temperature of transformation means that energy supply is big. The RA after holding for 10 min at $77 \mathrm{~K}$ is then: compressed less, has the lowest strength, relaxation processes in surrounding the RA the $\mathrm{M}$ took place sooner than in other specimens. Holding at $433 \mathrm{~K}$ for $10 \mathrm{~min}$ stabilise the RA after the second transformation, the RA is then compressed most, it has the highest strength ,the relaxation processes in the surrounding the RA, the $M$ took place later on than in other specimens. Scattering of the other results is so big that it is difficult to find reliable tendency. Results of this studies indicate that in $100 \mathrm{Cr} 6$ steel the RA exists even after holding for 35 min at $77 \mathrm{~K}$, and after second cooling to $77 \mathrm{~K}$.

\section{CONCLUSIONS}

1. Transformation the RA to the $\mathrm{M}$ at temperatures below $273 \mathrm{~K}$ proceeds in $100 \mathrm{Cr} 6$ steel and in $\mathrm{Fe}-\mathrm{N}$ and $\mathrm{Fe}-\mathrm{N}-\mathrm{C}$ alloys.

2. The biggest stabilisation of the RA in studied steel was found after holding for $35 \mathrm{~min}$ at the temperature range 291-373 K. The results and explanation are in agreement with earlier works.

3. The smallest stabilisation of the RA in studied steel was found after holding for $35 \mathrm{~min}$ at 77 and $433 \mathrm{~K}$. Small stabilisation at $433 \mathrm{~K}$ was discussed on the basis of earlier works. The most probable explanation is as follows :- the release of compressive stresses of the RA, -beginning of recovery of a cold deformed part of the RA , - and diffusion of carbon leading to a decrease of the carbon gradient in the RA. Small stabilisation at $77 \mathrm{~K}$ can be caused by the creation of austenite strain embryos from which the transformation can start.

\section{References}

[1]. Fletcher G. and Cohen M; Transactions of ASM vol.34, 1945 s. 216-236

[2]. Fletcher G., Averbach B.L.and Cohen M.; Transactions of ASM vol. 40, 1948 p.216

[3]. Averbach B.L., Cohen M.and Fletcher G.; ; Transactions of ASM vol.40, 1948 p. 728-757.

[4]. Maksimova O.P. and Ponyatovsky E.G.; Problems of Metallography and Physics of Metals ( Translated from Russian) 1959 , Consultants Bureau, Inc. New York, Chapman\& Hall , LTD London p.123-133

[5]. Lyask L.I. , Vovk Ya . N.and Polishchuk Yu.M.; Fiz.metal. metalloved., vol. 23 ,1967 p.898.

[6]. Lyask L.I., Vovk Ya . N. , Drachinskaya A.G. and Polishchuk Yu.M.; Fiz.metal metalloved., vol. 24,1967 p. 299.

[7]. Lysak L.I. and Andrushchik L.O.; Fiz.metal. metalloved., vol. 26,1968 p.380.

[8] Alshevskiy Yu.L.and Kurdiumov G.V. ; Fiz.metal. metalloved., vol. 25,1968 p.172.

[9] Alshevskiy Yu.L. ; Fiz.metal. metalloved., vol. 27,1969 p.147. 
[10] Lysak L.I. and Vovk Ya.N.; Fiz.metal. metalloved., vol: 31,1970 p.646.

[11]Yasuji Tanaka and Keichi Shimizu ; Trans. JIM ; vol.21, 1980,p 42.

[12] Ullakko K. and Pietikainen J.; Proceedings of The International Conference on Martensitic Transformation (1986) p.291 The Japan Institute of Metals.

[13] Edmondson B. and Ko T.; Acta Metallurgica, Vol.2 ,1954 p.235.

[14] Wierszyłlowski I. , Ryś J.: Nondestructive Characterisation of Materials II; Ed. : J.F.Busssiere,J.P.Monchalin , C. Ruud and R.E.Green, Jr. Plenum Press New York and London 1987 p.309.

[15] Belous M.V., Cherepin V.T., Vasiliev M.A.; Prevrashchenia pri otpuskie stali; Metallurgia 1973 Moskva (in Russian).

[16] Mitsuoka K. , Miyajima H., Ino H., and Chikazumi S.; Journal of the Physical Society of Japan, Vol.53, 1984 p.2381.

[17] Izotov V.I. , Utevskiy L.M. ; Fiz. metal. metalloved.Vol.25, 1968, p.751.

[18 ] Kittel C.;Introduction to Solid State Physics ; New York, John Wiley \& Sons, Inc. London, Chapman \& Hall , Ltd. p.303

[19] Chalmers B.: Physical Metallurgy ; New York, John Wiley \& Sons, Inc. London, Chapman \& Hall , Ltd. p.441

[20] Wierszyłłowski I. , Małdziński L.;Proceedings of High Nitrogen Steels HNS 88 the internationalconference held at Lille in France on May 18-20 1988, Edited by J.Foct, A.Hendry, The Institute of Metals 1989, p.338

[21] Ramachandran E.G., Dasarathy C.; Acta Metallurgica ; Vol.8. 1960 s.274

[22] Lysak .L.I., Andrushchik L.O.and Storchak N.A.; Fiz.metal. metalloved., Vol.29, 1970, p.841

[23] lzumiyama M. „Kinetics of Transformation of Aged Retained Austenite into Martensite” The 1040 th report of the Research Institute for Iron, Steel and Other Metals (1961).

[24] White G. and Brook R.; Metal Science ; 1977, p.152

[25] Hsu T.Y., Li Jian and Zen Zhengbeng; Metallography. Vol.19, 1986, p.305

[26] Breinan E.M.and Ansell G.S.; Metall.Trans. Vol.1,1970, p.1513

[27] Ankara A.; Journal of the Iron and Steel Institute ; 1970, p.819

[28]Honbing Chang and Hsu T.Y.: Acta Metall. Vol.34. 1986, p.325

[29] Rao B.V.N. and Thomas G. in Proc. Int. Conf. on „Martensitic Transformation ( ICOMAT )" Cambridge, Mass. USA 1979 p. 12

[30] Barnard S.J., Smith G.D., Sarikaya M. and Thomas G.; Scripta Metall. Vol.15. 1981, p.387

[31] Bhadeshia H.K.D.H. and Waugh A.R.; Acta Metallurgica Vol.15, 1981,p.387

[32] Bhadeshia H.K.D.H.; Metal Science, Vol.17, 1983 , p.151

[33] Hayakawa.M. , Tonigani M. , and M.Oka ; Metallurgical Trans. Vol.16A, 1985, 1745

[34] Krauss G. ; Proceedings of an International Conference on Solid - Solid Phase Transformations ; A publication of The Metallurgical Society of AIME p.101

[35] Cohen M., Machlin E.S. and Paranjpe V.G.; Thermodynamics in Physical Metallurgy , ASM Cleveland, Ohio 1949 p.162

[36] Olson G.B. and Cohen M.; Metallurgical Transactions, Vol.7A, 1976, p.1897

[37] Cohen M. ; Transactions of Japan Institute of Metals, Vol.29, No 8. 1988 p.609 